\title{
A STRATEGY IN DEVELOPING PASAR BUNGA RAWA BELONG AS A TOURIST DESTINATION IN WEST JAKARTA
}

\author{
Agung Gita Subakti( ${ }^{(1)^{*}}$, Asep Syaiful Bahri( ${ }^{(2)}$, Tiurida Lily Anita ${ }^{(3)}$
}

(1) \& (3) Hotel Management Department, Faculty of Economics and Communication, Bina Nusantara University

(2) Hotel Business Program, Podomoro University agsubakti@,binus.edu, asepsyaiful@podomorouniversity.ac.id, tiurida.anita@, binus.ac.id

Submitted: 2 June 2020 Revised: 20 August 2020

Accepted: 2 October 2020

\begin{abstract}
Pasar Bunga Rawa Belong is the biggest Pasar Bunga in Southeast Asia, with revenue over 15 billion rupiahs per month, and is also a residential area of ethnic Betawi. The Mayor of West Jakarta has already stated that Pasar Bunga Rawa Belong would be a tourist attraction with a gradual development to be considered. The Problem occurred in managing the development of the surrounding area which are the Government commitment in dealing with tourist destination concept, participation and public awareness of local people who are still low and incidental, the ability and capacity of each tourist destinations in accordance with its geographical condition, economical, and local culture making it difficult to manage, stakeholders participation and contribution are not yet optimal in the development of tourist destination. The purpose of this research is by creating a development strategy of Pasar Bunga Rawa Belong as a tourist destination and identifying the internal and external environment of Pasar Bunga Rawa Belong area.
\end{abstract}

Keywords: Development Strategy, Tourist Destination, Pasar Bunga Rawa Belong

\section{INTRODUCTION}

Tourism has a social role in reducing poverty and social harmonization. Among them are Sustainable Tourism-Eliminating Poverty or STEP (UNWTO, 2018). It is stated that the role of Indonesia tourism has been ranked $9^{\text {th }}$ from 176 countries and ranked $22^{\text {nd }}$ for the long-term contribution to the national economy in 10 years. Another important role of tourism is to preserve the environment that was triggered for a long time. In 1992, it has been approved some technical documents and global agreement connected with the concept of sustainability. The recommendation from DMO Conference held in Labuan Bajo, 21$22^{\text {nd }}$ September 2011 (beritapalu.com, 2011) mentioned that the management developed by the Indonesian government are the pro job, pro-growth, pro-poor and pro-environment principles that refer to the destination governance destination program. One of the things that

should be taken is in an effort to the formulation of superior destination concept, and therefore this competitiveness and sustainability can be achieved.

A tourist destination is a geographical area located within one or more administrative territory in which there are a tourist attraction, public facilities, tourism facilities, accessibility, as well as the tourism community or the people (ekowisata.org, 2009). Development and implementation of the innovative marketing strategies require changes in the definition and understanding the attraction, accessibility, and requirements 
that should be made available in a destination. Stankovic (2009) stated that the development of tourism must be conducted based on the sustainability criteria, meaning that developers are able to be supported ecologically in the long run and at the same time worthy in the economic term, fair ethically and socially for the community.

\section{LITERATURE REVIEW}

The audit program can be proposed to find out the last condition of a place. The audit process is a systematic check on economic and demographic: strengths, weaknesses, opportunities, and threats from a place, which in the end would become fundamental for developing a place to be better (Kotler, 2016). In this case, SWOT analysis can be used to formulating strategy, based on a comparison of the strengths, weaknesses, opportunities, and threats.

Creative tourism is a solution to experience by tourists in conventional tourism (Ababneh, 2017). There is a business model for creative tourism, that consist of five group elements. They are demand factors, supply factors, products and services, creative tourism tangible and intangible benefits, and financial results for the destinations (Ohridska-Olson, 2010).

Pasar Bunga Rawa Belong is the biggest Pasar Bunga in Southeast Asia, with revenue of over 15 billion rupiahs per month (Wahyuni, 2015). Historically Rawa belongs to a place of Betawi martial art called fingering and well known for Pitung, a robin hood of Betawi. It is also a residential area of ethnic Betawi. Therefore, Pasar Bunga Rawa Belong is also a place of interest to have a Betawi marriage ceremony and the traditional Betawi bridal finery (Abdullah, 2015). The problem occurred in managing the development of the surrounding area which is the Government commitment in dealing with tourist destination concept, participation and public awareness of local people who are still low and incidental, the ability and capacity of each tourist destinations which are different from one another in accordance with its geographical condition, economic and local culture making it difficult to manage. Stakeholders participation and contribution are not yet optimal in the development of tourist destination, and the preliminary assessment on the profile and map of a tourist destination has not been completed. Based on these findings, the purpose of this research is creating a development strategy of Pasar Bunga Rawa Belong as a tourist destination and identifying the internal and external environment of Pasar Bunga Rawa Belong area.

\section{RESEARCH METHOD}

According to Tjiptono and Gregorius (2011), the technique first presented by Martilla and James in 1977 inside their article "Importance Performance Analysis" which published in the Journal of Marketing. In this technique, respondents are asked to assess the level of importance and company performance, then the average value of the level of importance and performance. It is analyzed in the importance-performance matrix, which is the $\mathrm{X}$-axis $\mathrm{x}$ represents the perception while the Y-axis represents hope. The results are shown in the form of four quadrants of the cartesian diagram (Tjiptono and Gregorius, 2011). The interpretation of the quadrant are as follows:

A. Priority (Concentrate here). In this awareness, there are factors that are considered important and or expected consumers would, but the company's performance is assessed not satisfying so that the party companies need to concentrate on allocating resources power to improve performance that enters the quadrant this.

B. Maintain Achievement (Keep up the good work). In this awareness, there are factors that are considered important and expected as support in relation to customer satisfaction factor. Therefore, the company is obliged to maintain performance achievements.

C. Low Priority. In this awareness, there are factors that are considered to have a level 
of perception or low actual performance and not very important and or not too expected by consumers, therefore the company does not need to prioritize or pay more attention to these factors.

D. Excessive (Possibly overkill). In this awareness, there are factors that are

\section{RESULTS AND DISCUSSIONS}

As stated in the introductions, the tourism potential, according to our focus is at Pasar Bunga Rawa Belong, can be seen from factors like existing tourist attractions, the conditions of the amenities, accessibility conditions, and service conditions exist considered not too important and not too expected by the customer, therefore the company better allocate resources power related to these factors to more other factors have more priority levels high.
(Stankovic, 2012). The results of the survey are then graphed to illustrate the respondent's response regarding the condition or potential of tourism in Pasar Bunga Rawa Belong, and the graph is presented as follows:

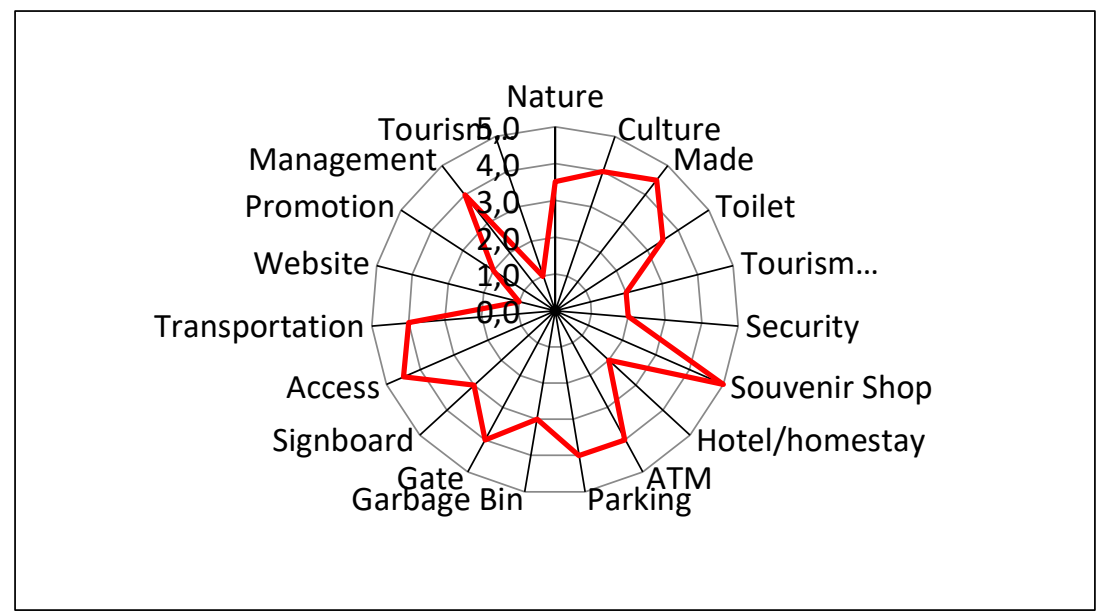

\section{Figure 1. Scat Tourism Potential of Pasar Bunga Rawa Belong. 2019 Primary Data Epl.: 1. Very Bad, 2. Not Good, 3. Good enough, 4. Good, 5. Very Good}

Based on Tourism Law at Indonesia number 10 of 2009 (Undang-Undang Pariwisata No. 10 Tahun 2009), tourist attractions consist of natural, cultural, and artificial. From the survey results, the condition of tourist attractions, in this case, is still very low. This is because the condition of Pasar Bunga Rawa Belong is only a part of a general market area in which there are flower sellers who sell their goods in the form of cut flowers, so from the natural potential of Pasar Bunga Rawa Belong, there are none of the natural potentials that support the tourism.

However, from the culture potential of Pasar Bunga Rawa Belong, it has good potential to be developed. This is considering that the area is in the Betawi tribe that still adheres to its customs. This Betawi tribe has its unique way on their cultures, food, dress, or events. Around the area of Pasar Bunga Rawa Belong, there are also many houses providing the brides dressing service independently and support the promotion of Betawi culture, as well as the culinary service business which typically serves Betawi foods.

In addition, at certain times, the Betawi culture festival is often held in Pasar Bunga Rawa Belong surrounding. Artificial tourism potential also has a great opportunity to develop. It has been known that Pasar Bunga Rawa Belong area is the largest Pasar Bunga in Indonesia, so it can hold any events related 
to "Bunga" or flower, such as the Betawi flower festival, typical Betawi culinary festival or other activities.

In terms of amenities, there are facilities of the potential tourism area that found in Pasar Bunga Rawa Belong. Toilet facility in Pasar Bunga Rawa Belong is dirty and not well maintained. Renovation of the toilet to make it bigger and clean is needed for the maintenance of the toilet. There is no information centre for tourists at Pasar Bunga Rawa Belong. This is understandable because people always think that the Pasar Bunga Rawa Belong is only a market that sells various kinds of cut flowers from all over Indonesia, therefore those who come to the market only want to buy flowers. The security facility, where the security guard is only a market security guard that is designated by the management of Pasar Bunga Rawa Belong or from the self-help of surrounding communities to maintain the security of the market environment.

Other facilities like souvenir shop are already integrated into the Pasar Bunga. The community considers that the flowers trade can be used as souvenirs for buyers. This caused by the main function of the Pasar Bunga Rawa Belong is a place to sell various kinds of flowers and not considered for doing tourism activities that support these locations.

While for a lodging facility, there is no proper homestay around the Pasar Bunga, where the tourists can stay and can interact with the surrounding community. The surrounding only provide a boarding or rented house for tourist to stay.

Other supporting facilities, like Automatic Teller Machine (ATM) are available. This is because many buyers came to Pasar Bunga Rawa Belong and needed an ATM to do the trading in the market.

Parking facilities are necessary to support the activities of buyers and sellers for loading and unloading goods. The parking conditions at Pasar Bunga Rawa Belong has not been neatly arranged. There is no division where parking for loading and unloading goods and parking for buyers.
Another condition that is not less important is the trash cans. The Pasar Bunga needs it for special handling of garbage that is available in Pasar Bunga Rawa Belong area. This condition is caused by the waste produced from garbage that is bought and sold, as well as supporting garbage such as styrofoam, plastic, cardboard, and others. Trash cans are not available in every corner of the market plus the awareness of traders who still have not noticed the cleanliness around them.

A signboard that reflects the identity of the tourist potential destination has not been seen at all. There is a gate before the entrance, but it didn't support the Pasar Bunga as a tourism destination. So many tourists don't aware of this place. A map of Pasar Bunga Rawa Belong area is available, to guide tourist or visitors to this Pasar Bunga area.

The access to the Pasar Bunga condition is good because the road to Pasar Bunga still uses the main road in perfect conditions, only the road width is narrow, so the central government needs policies to do road widening. For access to information about Pasar Bunga Rawa Belong on social media is not available. The management must consider making this as the promotion tools of the Pasar Bunga.

The services in Pasar Bunga Rawa Belong is minimum, tourist or visitor must serve themselves to get what they want from sellers. No clear information about product types or price. Every seller is seeing a tourist or visitor as a person, not as a valuable customer. When the awareness of the seller and the supporting people who work at the Pasar Bunga are still low, it is difficult to grow the image of the Pasar Bunga to be a potential tourism destination. The management must socialize to its market trader about service to the customer to upgrade the image of the Pasar Bunga. The communities surrounding must be considered as the supporting system to upgrade the image too. So, the socialization of how to do a great service to visitor or tourist can be developed inside the Pasar Bunga and from outside. 
In order to become a tourist destination, a development strategy for the Pasar Bunga Rawa Belong that pays attention to and involves the surrounding community is needed, which later it can be used as a reference in its development. The first thing to do in this research is to assess the importance and performance. In this case is what needs to be done to support the development activities of the area, based on the results of observations and questionnaires distributed to 100 respondents and interviews with community leaders the average importance value is 7.81 while for performance values it has an average of 5.80. This means that overall the development of Pasar Bunga Rawa Belong area has a high level of importance to be developed even though at this time it still has enough level of need. To determine the level of importance and performance in the development of Pasar Bunga Rawa Belong are presented in the following table:

Table 1. Average Assessment of Importance and Performance of Pasar Bunga Rawa Belong

\begin{tabular}{|l|l|c|c|}
\hline No & \multicolumn{1}{|c|}{ Keterangan } & Importance & Performance \\
\hline 1 & Nature & 8.35 & 3.47 \\
\hline 2 & Culture & 8.53 & 4.20 \\
\hline 3 & Artificial & 8.07 & 4.47 \\
\hline 4 & Toilet & 8.93 & 7.87 \\
\hline 5 & Tourism Information & 8.87 & 9.00 \\
\hline 6 & Security & 8.27 & 7.07 \\
\hline 7 & Souvenir Shop & 9.07 & 9.07 \\
\hline 8 & Hotel/homestay & 4.07 & 8.40 \\
\hline 9 & ATM & 8.67 & 4.27 \\
\hline 10 & Parking & 9.07 & 3.73 \\
\hline 11 & Garbage Bin & 8.60 & 4.67 \\
\hline 12 & Gate & 3.47 & 7.27 \\
\hline 13 & Signboard & 8.60 & 3.93 \\
\hline 14 & Access & 8.57 & 8.50 \\
\hline 15 & Transportation & 7.72 & 7.79 \\
\hline 16 & Website & 8.00 & 3.00 \\
\hline 17 & Promotion & 7.55 & 5.55 \\
\hline 18 & Management & 8.00 & 4.50 \\
\hline 19 & Tourism Awareness Community & 6.00 & 3.45 \\
\hline \multicolumn{2}{|l|}{ Total } & 7.81 & 5.80 \\
\hline
\end{tabular}

Source: Primary Data, 2019

Based on Table 1, the next step is to enter from each indicator of tourism potential into a graph that aims to determine the priority scale in developing the Pasar Bunga Rawa Belong as a tourist destination. Following is the importance-performance chart regarding the development of the Pasar Bunga Rawa Belong as a tourist destination.

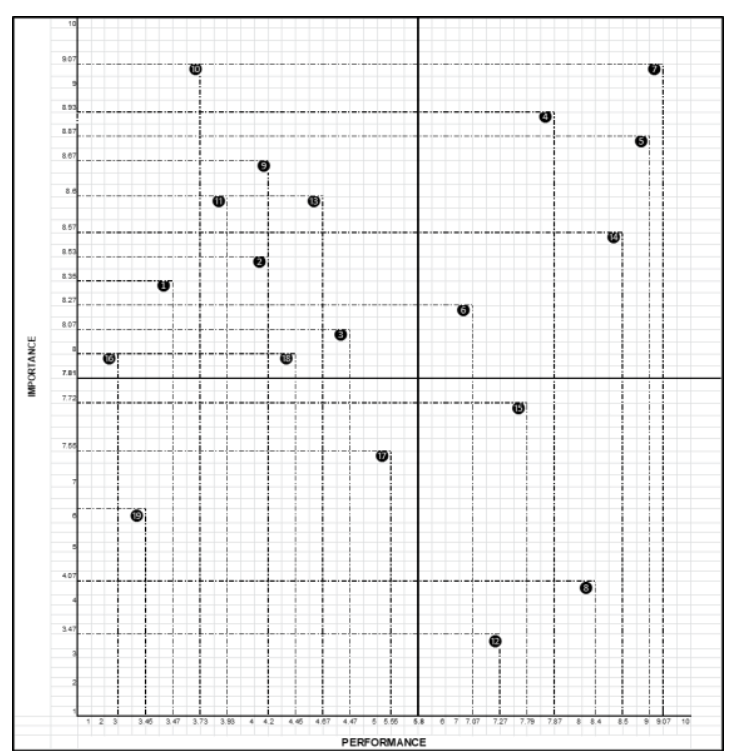

Figure 2. Importance and Performance Pasar Bunga Rawa Belong. Source: Primary Data, 2019

Figure 2 illustrates that there are activities from potential tourism indicators that enter quadrants. In quadrant I (priority) there are 9 (nine) indicators of tourism potential which later can be used as a reference in the development of the Pasar Bunga Rawa Belong. In quadrant II (keep it) there are 5 (five) indicators of tourism potential that can be maintained at this time as a support of the Pasar Bunga Rawa Belong. In the 'leave it' quadrant there are 2 (two) indicators of tourism potential which are currently not the main target in developing the Pasar Bunga Rawa Belong as a tourist destination, and for quadratic IV (second priority) there are 3 (three) indicators of potential tourism that can be expanded and improved to support the development of the Pasar Bunga Rawa Belong. Based on Figure 2 , it can be said that those included in the 4 (four) diagrams are presented in the following table:

Table 2. A Priority of Activities based on Importance Performance Quadrant

\begin{tabular}{lc}
\hline \multicolumn{1}{c}{ Information } & Quadrant \\
\hline Nature & \\
Culture & \\
Artificial & $1^{\text {st }}$ Quadrant \\
ATM & (First \\
Parking & Priority) \\
Garbage bin & \\
Signboard & \\
\hline
\end{tabular}


Agung Gita Subakti, Asep Syaiful Bahri, and Tiurida Lily Anita: A Strategy in Developing Pasar Bunga Rawa Belong as a Tourist Destination in West Jakarta

\begin{tabular}{lc}
\hline Website & \\
Management & \\
\hline Toilet & $2^{\text {nd }}$ \\
Tourism Information & Quadrant \\
Security & (Keep it) \\
Souvenir Shop & \\
Access & $3^{\text {rd }}$ \\
\hline Promotion & Quadrant \\
Tourism Awareness Community & (Leave it) \\
Group & $4^{\text {th }}$ \\
\hline Hotel/homestay & Quadrant \\
Gate & (Second \\
Transportation & Priority) \\
\hline
\end{tabular}

Source: Primary Data, 2019

\section{CONCLUSION}

The results are shown in the form of four quadrants of the cartesian diagram based on Tjiptono and Gregorius (2011). A priority (quadrant I) in the development of Pasar Bunga Rawa Belong are nature, culture, artificial, ATM, parking, trash, signboards, website, and management agency. The condition indicates that these things are very important to do in the initial stages of developing the Pasar Bunga Rawa Belong.

Next, supporting facilities (quadrant II) such as toilet, tourism information, security, souvenir shop, and accessibility become a second development priority after the first phase of the activity has been carried out. These factors need improvement and reinforcement to makes the tourists more comfortable.

Then, quadrant III that consisting of promotion and tourism awareness community groups. Both are very important to be improved to support the development of Pasar Bunga Rawa Belong as a tourist destination, but in fact, it does not need to be applied massively due to the area is not ready to become a tourist destination. A plan is needed to form tourism conscious in the community to support the development of Pasar Bunga Rawa Belong to become a tourist destination.

While for the second priority (quadrant IV) consists of hotels/homestays, gate, and transportation. Currently, the gate and transportation are already existing, and it seems that for the time being these two things won't be fixed or upgraded. Due to the status of Pasar Bunga Rawa Belong that is still not upgraded to be a tourist destination. The Pasar Bunga itself needs to be developed. Especially, additional attractions that can support the tourist interest and improve other facilities. While the hotel/homestay is currently not available, and unfortunately cannot be developed in the area if Pasar Bunga Rawa Belong is not becoming a tourist destination.

\section{REFERENCES}

Abdullah, N. (2015, March 9). RAWA BELONG: Pasar Bunga Segar Terbesar di Indonesia. Retrieved from Kabar 24: https://kabar24.bisnis.com/read/201503 09/386/410030/rawa-belong-pasarbunga-segar-terbesar-di-indonesia.

Al-Ababneh, M. (2017). Creative Tourism. Journal of Tourism \& Hospitality.

Fandi Tjiptono, C. G. (2011). Service Quality and Satisfaction. Yogyakarta: ANDI.

Ivanov, R. O.-O. (2010, November). Creative Tourism Business Model and Its Application In Bulgaria. Retrieved from Culture Realm: https://culturalrealms.typepad.com/files /creativetourismbm_article_1_lr.pdf

L. Stanković, S. ð. (2012). Marketing Theory and Practice Development. ," ECONOMIC THEMES, vol. 50, no. 4, 609-625.

Ljiljana Stanković, S. Đ. (2009). Challenges of Strategic Marketing of Tourist Destination under the Crisis Conditions. Facta Universitatis Series: Economics and Organization Vol. 6, No 1, 23 - 31.

Palu, B. (2011, September 21). Tata Kelola Destinasi Wisata Ditingkat dengan DMO. Retrieved from berita palu.com: https://beritapalu.com/2011/09/21/tatakelola-destinasi-wisata-ditingkatdengan-dmo/.

Pariwisata, K. (2009, January 16). UndangUndang Republik Indonesia Nomor 10 tahun 2009 tentang Kepariwisataan. Retrieved from www.ekowisata.org: https://www.ekowisata.org/uploads/file s/UU_10_2009.pdf. 
Agung Gita Subakti, Asep Syaiful Bahri, and Tiurida Lily Anita: A Strategy in Developing Pasar Bunga Rawa Belong as a Tourist Destination in West Jakarta

Philip Kotler, K. L. (2016). Marketing

Management 15th Edition. New York:

Pearson.

UNWTO. (2018, July 23). UNWTO,

"Tourism and Poverty Alleviation," July

23 2018. [Online]. Available: /.

Retrieved from http://step.unwto.org:

http://step.unwto.org

Wahyuni, T. (2015, February 13). Sekelumit

Kisah Pasar Bunga Terbesar di Asia

Tenggara. Retrieved from CNN

Indonesia:

https://www.cnnindonesia.com/gaya-

hidup/20150213121330-269-

31881/sekelumit-kisah-pasar-bunga-

terbesar-di-asia-tenggara 